\title{
Idiopathic granulomatous mastitis: an institutional experience
}

\author{
Seetharam Prasad ${ }^{1}$, Padmapriya Jaiprakash ${ }^{2}$, Aniket Dave ${ }^{1}$, Deepti Pai ${ }^{1}$
}

\begin{tabular}{|c|c|}
\hline \multirow[t]{5}{*}{ ABSTRACT } & $\begin{array}{l}\text { Objective: To study idiopathic granulomatous mastitis with respect to its various clinical features, etiologic factors, } \\
\text { treatment modalities and complications. }\end{array}$ \\
\hline & $\begin{array}{l}\text { Material and methods: Retrospective study of all patients who were diagnosed with idiopathic granulomatous mas- } \\
\text { titis from } 1^{\text {ts }} \text { January } 2006 \text { to } 31^{\text {st }} \text { December } 2014 \text { at Kasturba Hospital, Manipal, India (a tertiary care referral centre). } \\
\text { The research was performed according to the World Medical Association Declaration of Helsinki. Informed consent } \\
\text { was taken from the patient before invasive procedures including surgery. Data was analysed using the Statistical } \\
\text { Package for Social Sciences version } 16.0 \text { wherever appropriate. }\end{array}$ \\
\hline & $\begin{array}{l}\text { Results: } 73 \text { patients diagnosed with idiopathic granulomatous mastitis during the time period were included. One } \\
\text { patient was a male (1.37\%), rest were all females }(98.63 \%) \text {. The mean age of presentation was } 32.67 \text { years (range } 23 \\
\text { to } 66 \text { years). } 70 \text { patients }(95.89 \%) \text { were parous females. Average duration since last childbirth was } 4.6 \text { years (range: } 3 \\
\text { months to } 33 \text { years). } 8 \text { patients }(10.95 \%) \text { were lactating. History of oral contraceptive pill use was present in } 40 \text { patients } \\
(54.79 \%) \text {. The right breast was affected in } 44 \text { patients }(60.27 \%) \text {, and the left breast in } 29 \text { patients }(39.73 \%) \text {. None of the } \\
\text { patients had bilateral disease. The most common symptom was a painless lump }(61.64 \%) \text {. Rest of the patients (38.36\%) } \\
\text { presented with features of a breast abscess. } 19 \text { out of } 39 \text { FNACs done ( } 48.72 \%) \text { were positive for granulomatous mastitis. } \\
59 \text { were primarily managed surgically (lumpectomy/ wide excision-33, incision \& drainage- } 26) \text {. One patient was treated } \\
\text { primarily with prednisolone. } 13 \text { patients did not receive specific treatment, and were only kept on regular follow-up. } \\
\text { Patients managed with lumpectomy/ wide excision had the least rate of complications \& recurrence (18.18\%). }\end{array}$ \\
\hline & $\begin{array}{l}\text { Conclusion: Patients with idiopathic granulomatous mastitis can present with a wide variety of symptoms which } \\
\text { mimic other more common conditions. Surgical management in the form of wide excision appears to provide the } \\
\text { best long term outcome in patients with idiopathic granulomatous mastitis. }\end{array}$ \\
\hline & Keywords: Idiopathic, granulomatous, mastitis \\
\hline
\end{tabular}

Cite this paper as: Prasad S, Jaiprakash $P$, Dave A, Pai D. Idiopathic granulomatous mastitis: an institutional experience. Turk J Surg 2017; 33(2): 100-103

'Department of General Surgery, Kasturba Medical College, Manipal, India

2Department of Pathology, Kasturba Medical College, Manipal, India

Address for Correspondence Padmapriya Jaiprakash e-mail:padmapriya.j@gmail.com

Received: 02.11.2015 Accepted: 24.03.2016

\section{oCopyright 2017}

by Turkish Surgical Association

\section{INTRODUCTION}

Idiopathic granulomatous mastitis (IGM) is a rare, benign, chronic inflammatory condition of the breast. It was first described in 1972 by Kessler and Wolloch (1). Although it has been more than four decades since then the disease still remains an enigma. The etiology, natural course and treatment of choice of this condition are not yet well understood. Due to the rarity of the condition and the lack of sufficient studies, the prevalence of IGM is not known. Baslaim et al. (2) in their study reported that IGM represented $1.8 \%$ of 1106 cases of benign breast disorders which were subjected to a biopsy.

Idiopathic granulomatous mastitis typically presents as a lump in the breast with or without associated features of inflammation, in a parous woman of childbearing age. Clinically it may present with features similar to periductal mastitis (PDM). In fact, some authors consider IGM to be nothing but a variant of PDM $(3,4)$. The disease is usually unilateral, however, a few cases of IGM involving both breasts have been described (5). Diagnosis is further confounded by the fact that it often mimics carcinoma of breast, both clinically and radiologically $(1,6)$.

Histologically, a granulomatous inflammation is seen, which is closely related to the lobules. Granulomas composed of epithelioid histiocytes, Langhans giant cells accompanied by lymphocytes, plasma cells and occasional eosinophils are found within and around the lobules (7). The same cellular components are present in the FNA smears from these lesions (8). Histo-chemical stains for pathogens are usually negative. These findings have led to speculations of a cell mediated reaction to one or more substances in the mammary secretions of lobular cells, but no specific antigen has yet been identified (7).

Diagnosis of IGM is based on characteristic histological findings, after all possible infectious and noninfectious causes of granulomatous inflammation have been ruled out $(1,4,9)$. 
There are no universally accepted guidelines available for management of IGM. Surgery (complete excision or incision and drainage), corticosteroids, immunosuppressant therapy and expectant management are some of the treatment strategies which have been described in literature. Several studies have shown varying degrees of success with all of these methods. Furthermore, management is complicated by a high rate of recurrence (16-50\%) (9-11).

Herein, we describe our institutional experience with IGM over a period of 8 years.

\section{MATERIAL AND METHODS}

Medical records database of Kasturba Hospital, Manipal (a tertiary care centre) was searched retrospectively to identify all patients who were diagnosed with IGM between $1^{\text {st }}$ January $2006-31^{\text {st }}$ December 2014. The research was performed according to the World Medical Association Declaration of Helsinki. Informed consent was taken from the patient before invasive procedures including surgery. As it is a retrospective study, no separate consent was taken for inclusion in the study. For a patient to be included in the study, a histological diagnosis of granulomatous mastitis was required on core needle biopsy or open surgical biopsy. Furthermore, other causes of granulomatous mastitis had to be excluded. Finally, 73 such cases were identified and included in the study.

Patient characteristics, clinical features, etiologic factors, microbiologic studies, treatment modalities, complications and follow-up data for each patient were recorded and analysed. The variables were presented as mean, standard deviation, median, frequency and percent as appropriate. Data was analysed using the Statistical Package for Social Sciences version 16.0 (SPSS Inc.; Chicago, IL, USA).

\section{RESULTS}

During the study period, 73 patients were diagnosed with IGM in our hospital. Only one patient diagnosed with IGM was a male $(1.37 \%)$, the rest were all females $(98.63 \%)$. The mean age of presentation was 32.67 years, with a range of 23 to 66 years.

With the exception of three patients (including the one male patient), all the other patients $(70 ; 95.89 \%)$ diagnosed to have IGM were parous females. Average duration since last childbirth in those 70 patients was 4.6 years (range: 3 months to 33 years). 8 patients were lactating at the time of presentation.

Two of the 73 patients were smokers (2.74\%). History of oral contraceptive pill use at some point of time was present in 40 patients $(54.79 \%)$. None of the patients had a history of tuberculosis, sarcoidosis, connective tissue disease or any other infectious disease which could cause granulomatous inflammation.

The right breast was affected by the disease in 44 patients (60.27\%), and the left breast in 29 patients (39.73\%). None of the patients had bilateral disease. The most common site af-
Table 1. Fine Needle Aspiration Cytology (FNAC) findings

Granulomatous mastitis

19

Acute inflammatory features

10

Suggestive of malignancy

\section{Duct ectasia}

1

Inconclusive 8

Table 2. Adjuvant treatment after surgical management

\section{Surgery performed}

(total number)

ATT Prednisolone

\begin{tabular}{lll} 
Lumpectomy/ wide excision (33) & 9 & 2 \\
\hline I\&D (26) & 4 & 1
\end{tabular}

ATT: anti tubercular treatment; I\&D: incision and drainage

fected was the upper outer quadrant of the breast (32.88\%), followed by lower inner (21.92\%), upper inner (19.18\%), lower outer (13.69\%) and central (12.33\%) quadrants.

The most common presenting feature of the disease was a painless lump (61.64\%). Rest of the patients (38.36\%) presented with features similar to a breast abscess. $26.03 \%$ patients had fever at the time of presentation.

Fine needle aspiration cytology (FNAC) was performed in 39 patients (53.42\%), the findings are shown in Table 1.

Core needle biopsy and/or surgical excision specimens were sent for histopathologic examination in all cases, and were reported as granulomatous mastitis. Gram staining, bacterial culture and Ziehl-Neelsen staining were done for all patients to rule out infectious / tubercular mastitis.

All patients received antibiotics for variable time periods. The reason for antibiotic administration was either a suspected infectious pathology at the time of presentation or routine perioperative antibiotic coverage. The type, dosage and duration of antibiotic administration depended on the indication for antibiotic use and physician's personal preference.

59 patients underwent surgery as the primary treatment, 33 of them underwent lumpectomy/wide excision, and 26 underwent incision \& drainage. One patient was treated primarily with steroids (prednisolone). 13 patients did not receive any specific treatment initially and were kept on regular follow-up. Some patients received adjuvant antitubercular therapy (ATT) or prednisolone after surgical management (Table 2).

The occurrence of complications after the primary treatment is shown in table 3 . The patient treated primarily with prednisolone recovered completely, and had no complications at 6 month follow-up.

All 12 patients who developed recurrent/residual abscess were managed by I\&D. 6 of them recovered completely after $I \& D$, while the other 6 developed a persistent discharging 
Prasad et al.

Idiopathic granulomatous mastitis

Table 3. Complications associated with various treatment modalities

\begin{tabular}{|lcccccc|}
\hline $\begin{array}{l}\text { Primary treatment } \\
\text { (number of patients) }\end{array}$ & $\begin{array}{c}\text { Residual/ } \\
\text { Recurrent abscess }\end{array}$ & $\begin{array}{c}\text { Recurrent/ } \\
\text { Residual lump }\end{array}$ & Sinus & Ulcer & Mastalgia & $\begin{array}{c}\text { Total number of } \\
\text { complications }\end{array}$ \\
\hline Lumpectomy/ wide excision (33) & 3 & - & 2 & - & 1 & $6(18.18 \%)$ \\
\hline I\&D (26) & 7 & 7 & 5 & 2 & 2 & $23(88.46 \%)$ \\
\hline Prednisolone (1) & - & - & - & - & - & 0 \\
\hline Expectant (13) & 2 & 2 & 4 & 1 & - & $9(69.23 \%)$ \\
\hline Total & 12 & 9 & 11 & 3 & 3 & 38 \\
\hline
\end{tabular}

I\&D: incision and drainage

sinus and had to undergo excision of the sinus tracts. All of these patients eventually recovered.

Out of the 9 patients who had a residual lump at 6 months after primary treatment, 4 underwent lumpectomy and 5 were kept on regular follow-up. All 4 patients who underwent lumpectomy for residual lump recovered completely. 4 out of 5 patients who did not receive any treatment for the residual lump continued to have the same lump at 1 year follow-up, while one patient's residual lump regressed without any treatment.

11 patients developed a persistent discharging sinus during 6 months of follow-up. 8 of them underwent excision of the sinus tracts and the adjoining diseased breast tissues. All 8 of them recovered completely and were asymptomatic at 10 month follow-up. 3 of the patients were managed conservatively with a course of antibiotics as per the culture/sensitivity report and then kept on regular follow-up. In these 3 patients, the disease had a longer, protracted course, but eventually they all recovered (mean: 15.66 months, range: 13-18 months).

3 patients who had an ulcer at the operated site on the 6 month follow-up were all managed with local debridement and subsequent wound closure with secondary suturing. None of them had any further complications. Mastalgia in 3 patients was managed symptomatically with analgesics.

\section{DISCUSSION}

Idiopathic granulomatous mastitis is an enigmatic condition. Even though it was described more than 40 years ago, due to the rarity of this disease; its etiology, natural history and optimal treatment remain poorly understood. The disease is particularly troublesome for the patient because of its stubborn tendency to recur. Autoimmunity, pregnancy, lactation, hyperprolactinemia, oral contraceptive use, local trauma to the breast, alpha- 1 antitrypsin deficiency and smoking have all been described as risk factors for the occurrence of the disease (12-16).

A favourable response of the disease to steroids and immunosuppressant drugs has pushed forward the hypothesis of autoimmune nature of the disease. The etio-pathogenesis of the disease is thought to involve the following sequence of events: ductal epithelial damage, transition of luminal secretions to the lobular connective tissue, local inflammation in connective tissue, macrophage and lymphocyte migration to the region, and local granulomatous inflammatory response (14). However, the cause of ductal epithelial damage has not been recognized.

According to literature, IGM typically affects parous females in the reproductive age group $(1,12,13,17-19)$. These findings were confirmed in our study, although there were exceptions. 2 patients diagnosed with IGM were young nulliparous females, whereas there was also a post-menopausal lady suffering from the same disease. But the biggest exception, perhaps, was the diagnosis of IGM in a male patient. Previously, only one case of IGM in a male patient has been reported in the literature (20). 54.79\% patients had a history of use of OCPs, which is much higher than that reported in other studies.

The most common presenting symptom of patients with IGM was found to be a painless lump in the breast. FNAC as a tool for diagnosing IGM was not very efficient, as it had a high false-negative rate (51.28\%).

Most of the patients in the current study were managed primarily surgically. Wide excision/ lumpectomy was found to be the most effective treatment option, having the lowest rate of recurrence and complications. Surgical management with I\&D and expectant management were found to have an unacceptable high rate of complications and recurrence. Only one patient was managed primarily with steroids, and she recovered completely, with no recurrence or complications.

Expectant line of management with close follow-up was not found to be a satisfactory treatment option for IGM in the current study.

\section{Study limitation}

Due to the lack of adequate number of cases treated primarily with steroids, a satisfactory conclusion could not be drawn from the present study.

\section{CONCLUSION}

With 73 cases, this is one of the largest case series of Idiopathic granulomatous mastitis. The study reaffirms that this is a condition which is not easily understood. The patients can present with a wide variety of symptoms which mimic other more common conditions. Surgical management in the form of wide excision appears to provide the best long term outcome in patients with IGM. Although the use of corticosteroids has been advocated by some researchers, our experience with the same was limited to just one patient, hence we could not give a definite opinion on the same. 
Ethics Committee Approval: Authors declared that the research was conducted according to the principles of the World Medical Association Declaration of Helsinki "Ethical Principles for Medical Research Involving Human Subjects". (amended in October 2013).

Informed Consent: Written informed consent was obtained from patient who participated in this study.

Peer-review: Externally peer-reviewed.

Author Contributions: Concept - S.S.P., P.P.J.; Design - S.S.P.; Supervision - S.S.P., P.P.J.; Resource - S.S.P., P.P.J.; Materials - A.D., D.P.; Data Collection and/or Processing - A.D., D.P.; Analysis and/or Interpretation P.P.J., A.D.; Literature Search - P.P.J., A.D.; Writing Manuscript - A.D., D.P.; Critical Reviews - S.S.P., P.P.J.

Conflict of Interest: No conflict of interest was declared by the authors.

Financial Disclosure: The authors declared that this study has received no financial support.

\section{REFERENCES}

1. Kessler E and Wolloch Y. Granulomatous Mastitis: a lesion clinically simulating carcinoma. Amer J Clin Pathol 1972; 58: 642-646. [CrossRef]

2. Baslaim MM, Khayat HA, Al-Amoudi SA. Idiopathic granulomatous mastitis: A heterogeneous disease with variable clinical presentation. World J Surg 2007; 31: 1677-1681. [CrossRef]

3. Lester SC. Differential diagnosis of granulomatous mastitis. Breast J 2005; 11: 534-535. [CrossRef]

4. Mansel RE, Webster DJT, Sweetland HM, with the Collaboration of, Hughes LE, Gower-Thomas K, Evans DGR. In: Hughes, Mansel and Webster. Benign Disorders and Diseases of the Breast. $3^{\text {rd }}$ edition. Saunders Ltd; 2009. 281-282.

5. Pistolese CA, Trapano RD, Girardi V, Costanzo E, Poce ID, Simonetti G. An Unusual Case of Bilateral Granulomatous Mastitis. Case Rep Radiol 2013; 2013: 694697. [CrossRef]

6. Diesing D, Axt-Fliedner R, Hornung D, Weiss JM, Diedrich K, Friedrich M. Granulomatous mastitis. Arch Gynecol Obstet 2004; 269: 233-236. [CrossRef]

7. Inflammatory and reactive tumours. In: Paul Peter Rosen, editor. Rosen's Breast Pathology. $3^{\text {rd }}$ ed. Philadelphia: Lippincott Williams and Wilkins; 2009. p42-45.
8. Kobayashi TK, Sugihara H, Kato M, Watanabe S. Cytologic features of granulomatous mastitis. Report of a case with fine needle aspiration cytology and immunohistochemical findings. Acta Cytol 1998; 42: 716-720. [CrossRef]

9. Lai EC, Chan WC, Ma TK, Tang AP, Poon CS, Leong HT. The role of conservative treatment in idiopathic granulomatous mastitis. Breast J 2005; 11: 454-456. [CrossRef]

10. Bani-Hani KE, Yaghan RJ, Matalka II, Shatnawi NJ. Idiopathic granulomatous mastitis: time to avoid unnecessary mastectomies. Breast J 2004; 10: 318-322. [CrossRef]

11. Azlina AF, Ariza Z, Arni T, Hisham AN. Chronic granulomatous mastitis: diagnostic and therapeutic considerations. World J Surg 2003; 27: 515-518. [CrossRef]

12. Al-Khaffaf B, Knox F, Bundred NJ. Idiopathic Granulomatous mastitsis: a 25 year experience. J Am Coll Surg 2008; 206: 269-273. [CrossRef]

13. Kok KY, Telisinghe PU. Granulomatous mastitis: presentation, treatment and outcome in 43 patients. Surgeon 2010; 8: 197-201. [CrossRef]

14. Altintoprak F, Karakece E, Kivilcim T, Dikicier E, Cakmak G, Celebi F, et al. Idiopathic Granulomatous Mastitis: An Autoimmune Disease?. ScientificWorldJournal 2013; 2013: 148727. [CrossRef]

15. Cserni G, Szajki K. Granulomatous lobular mastitis following drug-induced galactorrhea and blunt trauma. Breast J 1999; 5: 398-403. [CrossRef]

16. Schelfout K, Tjalma WA, Cooremans ID, Coeman DC, Colpaert CG, Buytaert PM. Observations of an idiopathic granulomatous mastitis. Eur J Obstet Gynecol Reprod Biol 2001; 97: 260-262. [CrossRef]

17. Yau FM, Macadam SA, Kuusk U, Nimmo M, Van Laeken N. The Surgical Management of Granulomatous Mastitis. Annals of Plastic Surgery. Ann Plast Surg 2010; 64: 9-16. [CrossRef]

18. Mizrakli T, Velidedeoglu M, Yemisen M, Mete B, Kilic F, Yilmaz H, et al. Corticosteroid treatment in the management of idiopathic granulomatous mastitis to avoid unnecessary surgery. Surg Today 2015; 45: 457-465. [CrossRef]

19. Atak T, Sagiroglu J, Eren T, Ali Özemir I, Alimoglu O. Strategies to treat idiopathic granulomatous mastitis: Retrospective analysis of 40 patients. Breast Dis 2015; 35: 19-24. [CrossRef]

20. Reddy KM, Meyer CE, Nakdjevani A, Shrotria S. Idiopathic Granulomatous Mastitis in the Male Breast. Breast J 2005; 11:73.[CrossRef] 